\title{
Važnost zdravstvene edukacije u prevenciji ishemijske bolesti srca The importance of health education in the prevention of ischemic heart disease
}

Hajnalka Požar

\section{Sažetak}

Podaci Svjetske zdravstvene organizacije ukazuju da oko 17 milijuna ljudi godišnje umire u svijetu od bolesti srca i krvnih žila. Kardiovaskularne bolesti uzrokuju oko 49\% svih smrtnih ishoda. Nadalje, značajan su uzrok stupnja radne nesposobnosti, invaliditeta, troškova provođenja metoda zdravstvene zaštite i prijevremene smrtnosti. U socioekonomski razvijenim zemljama, zahvaljujući organiziranim preventivnim mjerama i zdravstvenoj edukaciji, došlo je do opadanja učestalosti i smanjenja stopa mortaliteta uzrokovanih kardiovaskularnim bolestima, što pokazuje potencijal za uporabu metoda prevencije. Analiziramo čimbenike rizika za nastanak kardiovaskularnih bolesti u konceptu značajnosti utjecaja zdravstvene edukacije i modifikacije načina života, a to su: povišeni krvni tlak, dijabetes, hiperlipidemija, pretilost, neadekvatna tjelesna aktivnost, pušenje i dati su savjeti za uspješno provođenje zdravstvenoodgojnog rada s pacijentima.

Ključne riječi: ishemijska bolest srca • faktori rizika • prevencija • zdravstveni odgoj

Kratki naslov: Prevencija kardiovaskularnih bolesti

\begin{abstract}
Data from the World Health Organization shows us that approximately 17 million people die every year from heart and blood vessel diseases worldwide. Cardiovascular diseases are responsible for about $49 \%$ of all deaths. They are also a significant cause of disability, large health care costs and premature death. In socioeconomically developed countries, thanks to the organized preventive measures and health education, there has been a decline in the frequency and mortality rates from cardiovascular diseases, which shows great potential in the possibilities of prevention. In the paper we are analyzing the risk factors for cardiovascular disease which can affect health education and lifestyle modifications, such as: high blood pressure, diabetes, hyperlipidemia, obesity, inadequate physical activity, smoking and there are also given tips for the successful implementation of health education work with patients. Key words: ischemic heart disease $\bullet$ risk factors $•$ prevention $•$ health education Running head: Prevention of cardiovascular disease
\end{abstract}

Autor za korespondenciju/Corresponding author: Hajnalka Požar, Medicinska škola „7.april", Vojvode Knićanina 1, 21 000 Novi Sad, Srbija, Profesor zdravstvene njege, Grabovačka 26., 24 000 Subotica, Srbija•Tel: +381(0)24-557-198•Mob: +381(0)69-557-1980•E-mail:pozarh@gmail.com

\section{Uvod/Introduction}

Kardiovaskularne bolesti (KVB), posebice koronarna bolest i moždani udar, danas predstavljaju vodeći uzrok smrtnosti u razvijenim zemljama, ali i u zemljama u razvoju. U ranim pedesetim godina prošlog stoljeća u industrijski razvijenim zemljama dolazi do značajnog porasta incidencije ovih bolesti. Tih je godina KVB smatran najvažnijim zdravstvenim problemom.

U zdravstveni sustav počinju se uvoditi metode koje su bile ograničene za potrebe liječenja i rehabilitacije. To je uzrokovalo značajan porast ekonomskih troškova, međutim izostali su učinci smanjenja obolijevanja. Rezultati istraživanja publiciranih tijekom posljednjih nekoliko desetljeća doveli su do novih saznanja o čimbenicima koji su povezani s porastom učestalosti KVB-a, i verificirali mogućnost smanjenja incidencije KVB-a, odnosno da se KVB (ishemijska bolest srca, cerebrovaskularnebolesti, periferna arterijska bolest) može značajno smanjiti.

To je dovelo do značajne prekretnice i orijentacije na izučavanje i svakodnevnu primjenu metoda prevencije, te do veće važnosti zdravstvenog odgoja [1,2]. Cilj je rada analizirati mogućnosti prevencije KVB-a, istaknuti na koje čimbenike možemo utjecati uporabom metoda zdravstvenog odgoja, što je jedna od osnovnih zadaća medicinskih sestara/tehničara (MS/MT), te u kojem obimu pre- ventivne metode utječu na smanjenje incidencije KVB-a te posljedično umanjuju javnozdravstveni problem suvremenog društva.

\section{Epidemiologija}

Ishemijska bolest označava grupu bolesti srca koje nastaju zbog smanjenja protoka krvi kroz koronarnu cirkulaciju. Jednostavnije, dolazi do poremećaja u ravnoteži između potreba miokarda za kisikom i mogućnostima opskrbe uslijed promjena na koronarnim krvnim žilama, koji su u 90\% slučajeva uzrokovani aterosklerozom. Ateroskleroza je degenerativno oboljenje arterija malog i velikog volumena. Nastaju promjene na intimi krvne žile, zbog stvaranja fibroznog (ateromatoznog) plaka i nagomilavanja masnoća (kolesterola, LDL lipoproteina, triglicerida) ispod njegove površine, što uzrokuje suženje lumena krvne žile [Slika 1].

Na neke čimbenike rizika nastanka ateroskleroze ne može se utjecati (naslijeđe, dob i spol), ali postoje i čimbenici rizika na koje je moguće utjecati preventivnim metodama (povišen krvni tlak, dislipidemija, šećerna bolest, pretilost, nepravilna prehrana, tjelesna neaktivnost i pušenje) [3]. 


\section{Atherosclerosis}

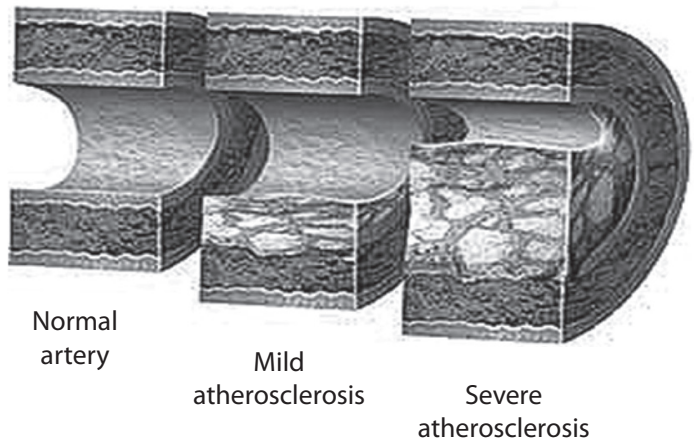

SLIKA [1] Mehanizam stvaranja stenoze intraluminalno.

Podaci Svjetske zdravstvene organizacije [SZO] ukazuju da oko 17 milijuna ljudi godišnje u svijetu umire od posljedica bolesti srca i krvnih žila. Kardiovaskularne bolesti uzrokuju oko $49 \%$ svih smrtnih ishoda (55\% svih uzroka smrti za muškarce i $43 \%$ za žene). Oko 30\% izgubljenih godina života u Europi posljedica je smrti uslijed kardiovaskularnih bolesti, a ishemijska bolest srca, zasebno promatrana, najčešći je uzrok smrtnosti u Europi. Više od trećine umrlih uslijed kardiovaskularnih oboljenja pripadaju osobama srednje životne dobi (radni dio opće populacije starosne dobi između 45. i 55. godine života.). Kardiovaskularne bolesti značajan su uzrok radne nesposobnosti, invaliditeta, velikih troškova zdravstvene zaštite i prijevremene smrtnosti [4].

Kralj V. [5] navodi da su u Republici Hrvatskoj [RH] kardiovaskularne bolesti vodeći uzrok smrti s udjelom od 49,2\% u ukupnom mortalitetu u 2010. godini. Uzrok su smrti 55,7\% kod žena (14 702) i 42,6\% kod muškaraca (10 929). Među ukupno umrlima od bolesti srca i krvnih žila 2010. godine $11 \%$ ih je u dobi do 64 godine. Muškarci u znatno većem obimu umiru u dobi do 64 . godine života (19,3\%), odnosno 2111 umrlih muškaraca, u odnosu na žene $(4,7 \%)$ odnosno 695 umrlih žena. Vodeće dijagnostičke podskupine ishemijske su bolesti srca s udjelom od 21,6\% (11 264 umrle osobe) i cerebrovaskularne bolesti s udjelom od 14,6\% (7 610 umrlih osoba) u ukupnom mortalitetu, zatim slijede srčana insuficijencija s 1798 umrlih osoba (3,5\%) i hipertenzija s 1638 umrlih $(3,1 \%)$.

Opisani rezultati pokazuju da bi najveće produljenje očekivanog trajanja života nastalo smanjenjem mortaliteta od ishemijske bolesti srca kod muškaraca i eliminacijom cerebrovaskularnih bolesti kod žena. Ovo se postiže uporabom metoda tzv. zdravog načina života, edukacijom koja se provodi od djetinjstva s posebnom pažnjom prema rizičnim skupinama i modifikacijom štetnih čimbenika koji su povezani s kardiovaskularnim bolestima [6]. U socioekonomski razvijenim zemljama, zahvaljujući organiziranim preventivnim mjerama i zdravstvenoj edukaciji, došlo je do opadanja učestalosti i smanjenja stopa mortaliteta od KVB-a, što ukazuje na veliku korist uporabe metoda prevencije u bolesnika s KVB-om.

\section{Osnovna načela prevencije}

U smanjivanju incidencije kardiovaskularnih oboljenja, poseban akcent treba staviti na metode primarne prevencije. Najbolji se rezultati mogu postići upotrebom interventnih programa koji uključuju metode promocije zdravlja, prevencije i kontrole. Prevencija KVB-a doprinosi povećanju stupnja kvalitete života opće populacije.
Metode prevencije u uporabi su unapređenja i očuvanja zdravlja, i uspostavljanja narušenog zdravlja. Nije li sve ovo moguće, tada su usmjerene usporavanju nepovoljnog tijeka i ishoda bolesti [7]. Vrste prevencije koronarne bolesti su primordijalna, primarna, sekundarna i tercijarna. [Slika 2]

1. Primordijalna prevencija. Cilj primordijalne prevencije sprječavanje je nastanka uvjeta u društvu za koje se zna da povećavaju rizik obolijevanja i uspostavljanje ekonomskih, socijalnih i bihevioralnih uvjeta sredine za stvaranje takvih uvjeta. Na žalost, mogućnosti za primordijalnu prevenciju su ograničene, jer su mnogi čimbenici rizika prisutni u većini zemalja.

2. Primarna prevencija. Cilj je smanjenje incidencije bolesti. To su postupci koje treba provesti kako ne bi došlo do nastanka bolesti. Prevencija kardiovaskularnih bolesti u primarnoj prevenciji zasniva se na dvije strategije koje se istovremeno primjenjuju:

a) Populacijska strategija primjenjuje se na cjelokupno stanovništvo. Cilj je smanjiti loše navike stanovnika koji su osnovni uzroci pojave KVB-a (npr. prehrana, pušenje, tjelesna ativnosti), odnosno kod djece i mladih usvojiti metode zdravog načina života i ponašanja. Među čimbenicima rizika koji se mogu modificirati jesu: pušenje, nepravilna prehrana i tjelesna neaktivnost. Zdravstveno-odgojne metode usmjerene na opću populaciju od najvećeg su socioekonomskog značaja za smanjenje KVB-a.

b) Strategija visokog rizika usmjerena je k pojedincu. Strategija identificira pojedinaca s visokim rizikom za nastanak KVB-a. Podrazumijeva uporabu metode za smanjivanje čimbenika rizika i pravovremeno liječenje. U ovom pristupu izravnu ulogu imaju kliničari i zdravstveni radnici, koji provode tzv. screening-otkrivanje i preventivne metode kod osoba s povišenim rizikom za nastanak KVB-a.

3. Sekundarna prevencija. To su metode ranog i pravovremenog otkrivanja oboljenja, brzog i uspješnog dijagnosticiranja i usmjerene su protiv progresije ili recidiva KVB-a kod osoba koje imaju klinički razvijenu koronarnu bolest. Tako primarna prevencija označava prevenciju nastanaka ateroskleroze, dok sekundarnu prevenciju ishemijske bolesti srca čini liječenje, tj. usporavanje procesa ateroskleroze. $U$ ove metode uvrštavaju se i medikamentno, interventno kardiološko i kardiokirurško liječenje.

4. Tercijarna prevencija. Cilj je ograničavanje nesposobnosti i rehabilitaciju osoba s razvijenim KVB-om i poboljšanje stupnja

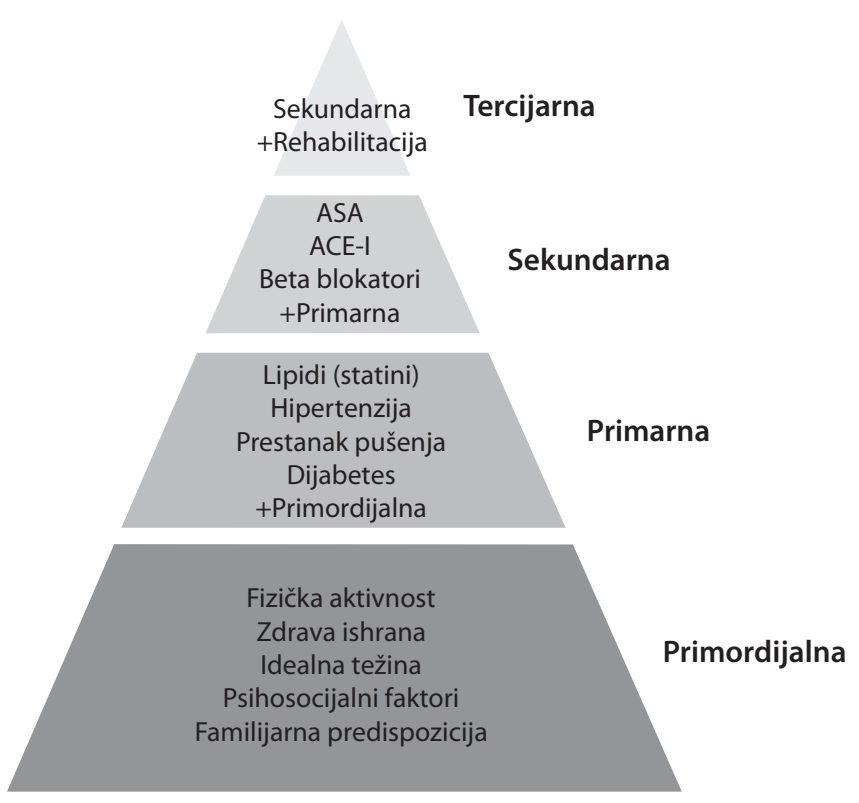

SLIKA [2] Metode prevencije. 
kvalitete života, jednostavnije - to su metode liječenja. Kardiološka rehabilitacija je proces osposobljavanja srčanih bolesnika za obavljanje aktivnosti svakodnevnog života. To su dugotrajni programi koji uključuju metode tjelesne aktivnosti, savjetovanje u svezi uporabe postupaka za modifikaciju čimbenika rizika nastanka i edukaciju o KVB-u $[8,9]$.

\section{Čimbenici rizika za nastanak kardiovaskularnih oboljenja}

Čimbenici su rizika stanja, oboljenja ili navike uz koje pojedini zdravstveni problemi imaju veću incidenciju. Glavni čimbenici rizika oni su za koje rezultati publiciranih istraživanja verificiraju da znatno povećavaju rizik za nastanak KVB-a. Ostali čimbenici povezani s povećanim rizikom, ali njihova važnost i učestalost još uvijek nije znanstveno verificirana. To su takozvani doprinosni/predisponirajući čimbenici rizika. Glavni čimbenici rizika za ishemijsku bolest srca i razvoj ateroskleroze jesu: pušenje; arterijska hipertenzija (povišen krvni tlak); dislipidemija, odnosno hiperlipidemija (povišene vrijednosti LDL-a i nizak HDL-kolesterol); šećerna bolest; starija životna dob (muškarci $>55$ god. i žene nakon menopauze $>65$ god.). Predisponirajući čimbenici rizika za razvoj ateroskleroze i koronarne bolesti jesu: pretilnost (naročito abdominalna); nedovoljna tjelesna aktivnost i neadekvatan način prehrane (povećan unos alkohola i soli); pozitivna obiteljska anamneza (genetska predispozicija); psihosocijalni čimbenici (stres) [10].

Čimbenici rizika dijele se i na temelju toga možemo li utjecati na njih preventivnim metodama ili ne. U cilju otkrivanja prisutnih čimbenika rizika, pri kontaktu s pacijentom potrebno je identificirati glavne čimbenike rizika (hipertenzija, pušenje, dislipidemije, starost, pozitivna obiteljska povijest) i čimbenike rizika životnih navika (pretilost, tjelesna neaktivnost, neadekvatan način prehrane, povećan unos alkohola i soli).

U svakodnevnom radu MS/MT na kardiološkim odjeljenjima provodi kontinuiranu edukaciju bolesnika, koja je od važnosti jer omogućuje bolesnicima bolje razumijevanje etiologije bolesti $\mathrm{i}$ mogućnostima prevencije i liječenja. Ciljevi edukacije su upoznavanje bolesnika s čimbenicima rizika, simptomima i znakovima ishemijske bolesti srca, mogućnostima i načinima liječenja te važnosti promjena životnih navika i redovitog uzimanja lijekova [11].

Prema nacionalnom planu i programu za prevenciju bolesti srca i krvnih žila, izrađene su mjere, kojima se ukazuje na potrebu informiranja, educiranja i poticanja stanovništva na prihvaćanje zdravijeg načina života i mijenjanje štetnih navika. Preporuke SZO-a iznalaze potrebu suradnje zdravstvenih djelatnika na svim razinama zdravstvene zaštite radi sprečavanja i suzbijanja čimbenika rizika. Budući da su MS-ovi/MT-ovi najbrojniji djelatnici u sustavu zdravstva neophodno je poboljšati stupanj razumijevanja o važnosti MS-a/MT-a u prevenciji KVB-a. Boljim razumijevanjem čimbenika rizika i njihovim otklanjanjem mogu se poboljšati krajnji ishodi liječenja.

Visoko obrazovane medicinke sestre, koje su stekle potrebna znanja i vještinu za planiranje aktivnosti programa prevencije, dijagnostike i liječenja KVB-a, imaju mogućnosti da edukativnim akcijama preuzmu najznačajnije mjesto u smanjenju morbiditeta i mortaliteta KVB-a [12].

\section{Čimbenici rizika na koje je moguće utjecati upotrebom metoda zdravstvenog odgoja i modifikacijom načina života}

Postoje čimbenici rizika na koje možemo utjecati (promjenom načina života, uzimanjem lijekova), i na taj način prevenirati pojavu
KVB-a. Reduciranje navedenih čimbenika rizika zahtijeva podršku članova obitelji, okoline kao i društvenih čimbenika.

\section{Arterijska hipertenzija}

Povišeni krvni tlak (sistolički tlak iznad $140 \mathrm{~mm} \mathrm{Hg}$, dijastolički iznad $90 \mathrm{~mm} \mathrm{Hg}$ ), dovodi do oštećenja endotelakrvnih žila, koje uzrokuje taloženje masnoća i stvaranja aterosklerotskog plaka. Metode prevencije i edukacije kod arterijske hipertenzije:

identifikacija, tj. screening visokorizičnih osoba i njihovo uključivanje u preventivni program. Kod osoba s verificiranom hipertenzijom potrebno je poduzeti preventivne mjere i educirati pacijenta:

- da promjene način prehrane (osobito smanje unos soli i alkohola),

- da provode redovitu tjelovježbu, i normaliziraju tjelesnu težinu (kod pretilih osoba),

- da izbegavaju stresne situacije i prestanu pušiti,

- treba preporučiti redovite kontrole krvnog tlaka,

- upoznavati ih s medikamentnom terapijom i liječenjem preporučenim od kardiologa [13]. [Tablica 1]

TABLICA [1] Referentne vrijednosti arterijskog tlaka

\begin{tabular}{lccc}
\hline Kategorija (stupanj) & $\begin{array}{c}\text { Sistolički/dijastolički } \\
\text { tlak (mmHg) }\end{array}$ \\
\hline Optimalna & $<120$ & i & $<80$ \\
\hline Normalna & $<129$ & i & $<84$ \\
\hline Visoko normalno & $130-139$ & i & $85-89$ \\
\hline Hipertenzija 1 st.- blaga & $140-159$ & i & $90-99$ \\
\hline Hipertenzija 2 st.- umjerena & $160-179$ & i & $100-109$ \\
\hline Hipertenzija 3 st.- ozbiljna & $\geq 180$ & i & $\geq 110$ \\
\hline ISH - Izolirana sustavna hipertenzija & $\geq 140$ & i & $<90$ \\
\hline
\end{tabular}

*2007 Guidelines for the management of arterial hypertension. European Heart Journal 2007;28:1462-1536.

\section{Pušenje kao čimbenik rizika}

Nikotin sužava krvne žile, a ugljični monoksid može oštetiti unutrašnjost krvnih žila, što ih čini osjetljivim na početak procesa ateroskleroze. Svakom pušaču treba savjetovati da prestane pušiti. Savjet daje najbolje rezultate kod osoba koje su spremne i motivirane za prestanak pušenja. Ponavljanje o kardiovaskularnim rizicima i štetnostima od posebnog je značaja, liječnici i MS-ovi/ MT-ovi moraju biti primjer pacijentima time što ne puše. Izuzetno je važna i podrška okoline. Potrebno je provoditi edukativne programe posebice među mladima, informirati opću populaciju o štetnom djelovanju duhanskog dima te osigurati radni i životni prostor bez duhanskog dima. Omogućiti stručnu, medicinsku i psihološku pomoć, onima koji žele prestati pušiti i pohađati programe za odvikavanje od pušenja [14].

Prevencija i prestanak pušenja najučinkovitija je metoda unapređivanja zdravlja, jer je pušenje povezano s povećenim rizikom nastanka mnogih bolesti (npr. maligne bolesti, koronarna bolest, moždani udar, kronična opstruktivna bolest pluća). [Slika 3] 


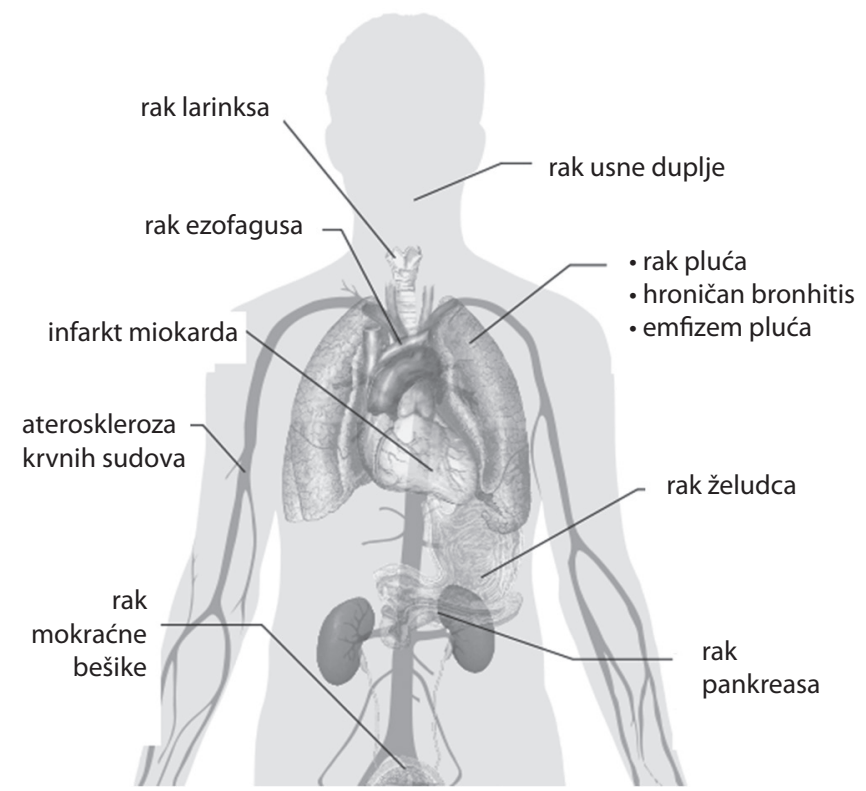

SLIKA [3] Štetni učinci duhanskog dima.

\section{Hiperlipidemija}

Povišene koncentracije ukupnog i LDL-kolesterola povećavaju rizik za razvoj ateroskleroze i nastanak ishemijske bolesti srca. Aterogeni učinci LDL-kolesterola dodatno pojačavaju niske vrijednosti HDL-kolesterola, uz ostale faktore rizika, npr, pušenje, hipertenziju i šećernu bolest. [Tablica 2]

Savjeti za snižavanja lipida u krvi jesu: promijena dosadašnjeg stila života, prije svega odgovarajućom dijetetskom prehranom; povećanje tjelesne aktivnosti (pri kojoj se osoba najmanje $30 \mathrm{mi}-$ nuta bavi poslovima u kojima je povećan gubitak energije), i održavanjem tjelesne težine u normalnim granicama [13].

TABLICA [2] Klasifikacija parametara lipidskog ili poproteinskog statusa

\begin{tabular}{lll}
\hline Ukupni kolesterol & poželjno & $<5,2 \mathrm{mmol} / \mathrm{I}$ \\
\cline { 2 - 3 } & granično visoko & $5,20-6,19 \mathrm{mmol} / \mathrm{I}$ \\
\cline { 2 - 3 } & visokorizično & $\geq 6,20 \mathrm{mmol} / \mathrm{I}$ \\
\hline \multirow{2}{*}{ Trigliceridi } & poželjno & $<1,7 \mathrm{mmol} / \mathrm{I}$ \\
\cline { 2 - 3 } & granično visoko & $1,7-2,29 \mathrm{mmol} / \mathrm{I}$ \\
\cline { 2 - 3 } & visokorizično & $\geq 2,30 \mathrm{mmol} / \mathrm{I}$ \\
\hline HDL-kolesterol & poželjno & $\geq 1.60 \mathrm{mmol} / \mathrm{I}$ \\
\cline { 2 - 3 } & graničano visoko & $1,01-1,59 \mathrm{mmol} / \mathrm{I}$ \\
\cline { 2 - 3 } & visokorizično & $\leq 1,00 \mathrm{mmol} / \mathrm{I}$ \\
\hline \multirow{2}{*}{ LDL-kolesterol } & optimalno & $<2,6 \mathrm{mmol} / \mathrm{I}$ \\
\cline { 2 - 3 } & poželjano & $<3,4 \mathrm{mmol} / \mathrm{I}$ \\
\cline { 2 - 3 } & granično visoko & $3,4-4,1 \mathrm{mmol} / \mathrm{I}$ \\
\cline { 2 - 3 } & visokorizično & $\geq 4,10 \mathrm{mmol} / \mathrm{I}$ \\
\hline
\end{tabular}

\section{Diabetes mellitus (šećerna bolest)}

Bolest se očituje postojanjem hiperglikemije zbog poremećaja u sekreciji inzulina (genetski čimbenici i čimbenici okoline ko- ji najčešće djeluju združeno). Procesi intracelularnog oksidativnog stresa uzrokuju oštećenja bazalne membrane krvne žile što dovodi do izmijenjene funkcije i razvoja ubrzane ateroskleroze. [Slika 4]

Preventivne metode sadržavaju: određivanje rizične populacije, edukaciju te populacije o bolesti i načinu prehrane, redovite kontrole vrijednosti šećera u krvi; edukaciju o načinu liječenja; dijetoterapiju; smanjenje tjelesne težine i povećanje fizičke aktivnosti prve su mjere liječenja kod oba tipa dijabetesa. Kod bolesnika s dijabetesom tipa 1 neophodna je terapija inzulinom, te bolesnike, a tako i članove njihovih obitelji treba educirati za pravilnu aplikaciju inzulina i prepoznavanje simptoma hiper i hipoglikemije i samostalno mjerenje razine šećera u krvi.

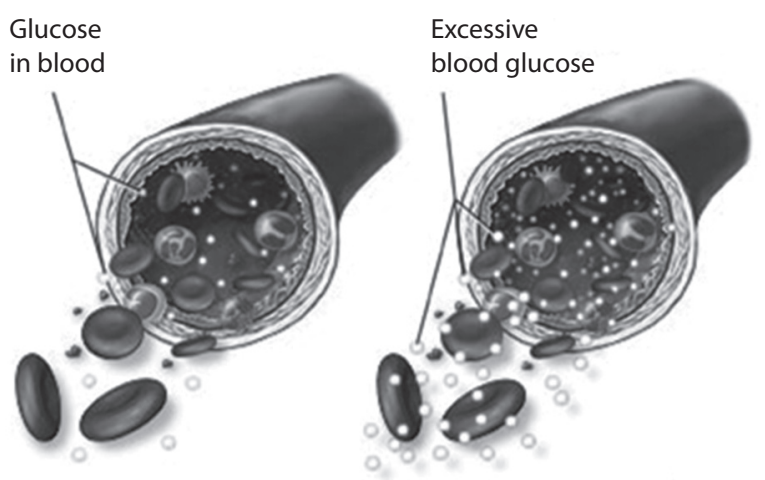

SLIKA [4] Intraluminalni patofiziološki proces u bolesnika s povišenim vrijednostima glukoze u krvi.

Kod bolesnika s tipom 2 šećerne bolesti ako promjena načina života ne daje zadovoljavajuće rezultate, primjenjuje se terapija oralnim hipoglikemicima, te i terapija inzulinom [15].

\section{Pretilost i nepravilna prehrana}

Prekomjerno nagomilavanje masnog tkiva u tijelu, osobito oko struka (abdominalni tip), predstavlja čimbenik rizika za razvoj ateroskleroze. Pretilost je najčešće udružena s hipertenzijom, dijabetesom tipa 2 i hiperlipidemijom koji zajedno čine visokorizične čimbenike za razvoj KVB-a. U cilju prevencije KVB-a, aktivnosti trebaju biti usmjerene ka otkrivanju rizične populacije i smanjenju tjelesne mase kod osoba $s$ indeksom tjelesne mase iznad 25 $\mathrm{kg} / \mathrm{m}^{2}$. [Tablica 3]

TABLICA [3] Kategorije uhranjenosti prema BMI-ju i rizik komorbiditeta

\begin{tabular}{lcc}
\hline $\begin{array}{l}\text { Kategorija } \\
\text { uhranjenosti }\end{array}$ & $\begin{array}{c}\text { BMI - body mass } \\
\text { index }\left(\mathbf{k g} / \mathbf{m}^{2}\right)\end{array}$ & $\begin{array}{c}\text { Rizik od } \\
\text { komorbiditeta }\end{array}$ \\
\hline normalna uhranjenost & $18,5-24,9$ & prosječan \\
\hline prekomjerna uhranjenost & $\geq 25$ & \\
\hline predgojaznost & $25,0-29,9$ & lako povišen \\
\hline pretilost: & $\geq 30$ & \\
\hline - pretilost 1. stupnja & $30,0-34,9$ & umjereno povišen \\
\hline - pretilost 2. stupnja & $35,0-39,9$ & vrlo povišen \\
\hline - ekstremna pretilost & $\geq 40,0$ & višestruko povišen \\
3. stupnja & & \\
\hline
\end{tabular}


Budući da je pretilost posljedica prekomjernog energetskog unosa i/ili nedovoljne fizičke aktivnosti, pretile osobe treba educirati i motivirati da smanje tjelesnu težinu povećanjem tjelesne aktivnosti i smanjenjem energetskog unosa hrane. [Slika 5]

\author{
Metabolički sindrom \\ (sindrom X) \\ - abdominalna gojaznost \\ - povišen krvni pritisak \\ - povišeni trigliceridi \\ - nizak HDL-holesterol \\ - inzulinska rezistencija
}

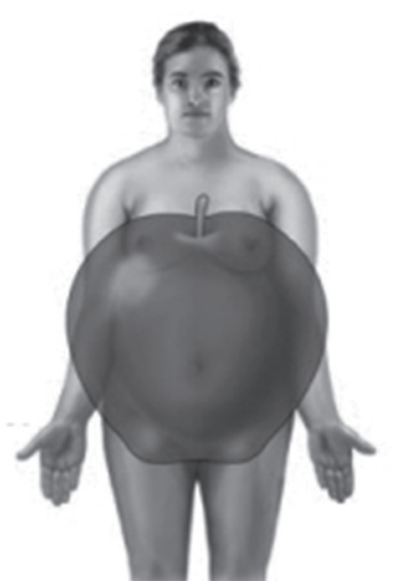

SLIKA [5] Metabolički sindrom (sindrom X).

Aktivnosti za unapređivanje načina prehrane su: edukacija u vezi s prehranom treba biti uvrštena u sve oblike zdravstvenog odgoja i obrazovnih programa;

posebice naglašavanje važnosti prehrane $u$ smanjenju tjelesne težine, sniženju vrijednosti krvnog tlaka, sniženju lipida u krvi i u kontroli glukoze u krvi. Dijetalna ishrana stil je života i ne može biti privremena, zato je u pristupu s ovakvim bolesnicima najvažniji dio edukacija o prehrani. Tijekom razgovora bolesnika treba educirati o dijeti koju će koristiti, izraditi popis namirnica koje je dopušteno unositi, predložiti raspored obroka i kalorijski unos i u suradnji s pacijentom definirati terapijski cilj. Treba pomoći bolesnicima u izračunu potrebnog energetskog unosa u odnosu na spol, dob i individualne aktivnosti, a članove obitelji potrebno je informirati o vrsti hrane koju treba odabrati, kako je pripremati i u kojim je količinama unositi u tijelo [16].

Edukacija opće populacije i rana prevencija kod djece imaju posebnu važnost. U školski program treba uključiti metode promocije pravilne prehrane i edukaciju o značaju tjelesne aktivnosti za pravilan psihofizički razvoj. Takav program prevencije ima najveći utjecaj na sprječavanje kasnijeg razvoja kroničnih bolesti. [Slika 6]

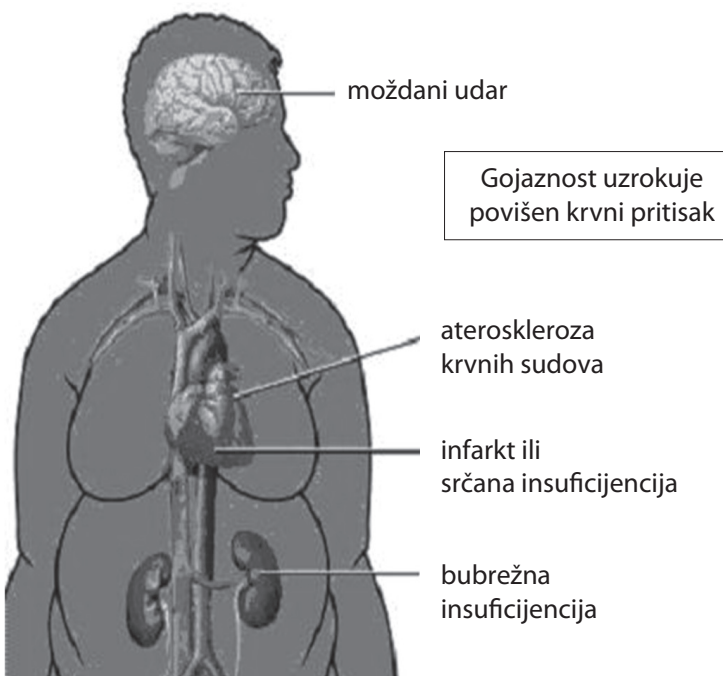

\section{Nedovoljna tjelesna aktivnost}

Fizički neaktivan način života ima značajnu ulogu u razvoju KVBa, zdravstveno-promotivni programi preporučuju tjelesnu aktivnost tijekom cijelog života. Redovito umjereno vježbanje smanjuje mortalitet, incidenciju KVB-a, dijabetes tipa 2, hipertenzije i dovodi do smanjenja tjelesne mase. [Slika 7]
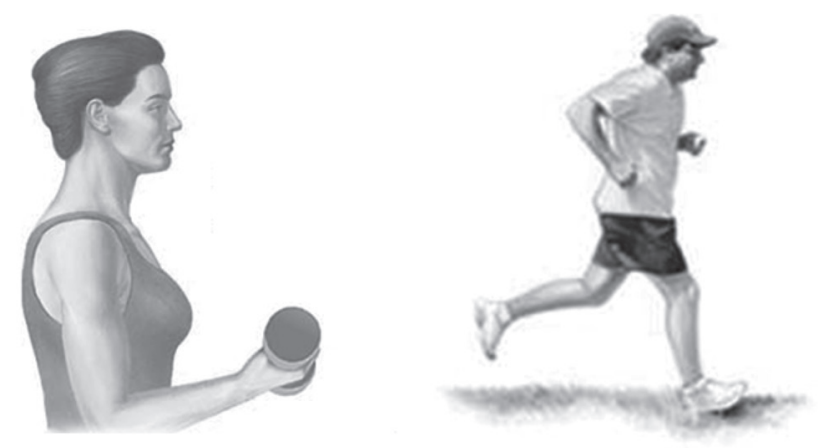

SLIKA [7] Tjelovježba je značajna metoda prevencije nastanka KVB-a.

Preporuka je početi fizičku aktivnost što ranije u životu u čemu značajnu ulogu ima tjelesni odgoj u školama. Pacijentima s klinički verificiranom KVB-om, preporuke za vježbe moraju se temeljiti na kliničkom mišljenju i rezultatima testova opterećenja. Trajanje fizičkih vježbi treba iznositi 30-40 minuta dnevno, minimalno 4-5 puta tjedno, a najbolje svakodnevno [17].

\section{Stres kao faktor rizika}

Stres uzrokuje fiziološke promjene (promjene krvnog tlaka, lipida u serumu, razine šećera, pulsa) i uzrokuje poremećaje ponašanja, a kao kompenzatorni se simptomi stresa javljaju: pušenje, alkoholizam, poremećaj prehrane, tjelesna neaktivnost, razni oblici depresije.

Kao prevencija i rehabilitacija bolesnika s KVB-om u uporabi su metode kontrole mentalnog stresa (npr. psihološke radionice i sportsko-rekreativne vježbe).

\section{Zaključak/Conclusion}

Najučinkovitiji način suzbijanja povećanja incidencije KVB-a uporaba je znanstveno verificiranih preventivnih metoda.

Ciljevi su provođenja metoda edukacije u svrhu prevencije,

na temelju najnovijih, znanstveno verificiranih saznanja i preporuka, poboljšati učinkovitost zdravstvenih djelatnika koji otkrivaju rizične skupine ljudi u općoj populaciji te edukacija navedenih skupina,isticanje potrebe ranog prepoznavanja osoba s čimbenicima rizika, u svrhu pravovremene uporabe terapeutsko dijagnostičkih postupaka i praktičnim savjetima olakšati modifikaciju načina života, tj. smanjiti stupanj morbiditeta i mortaliteta od KVB-a.

Posebnu pažnju treba posvetiti psihosocijalnim čimbenicima kako bi se od rane mladosti usvojile zdrave životne navike. Školski program treba sadržavati odgovarajuću edukaciju (mjere rane prevencije KVB-a)kako bi djeca usvojila pojmove kao što su zdrava hrana, tjelovježba i psihofizički razvoj.

\section{Authors declare no conflict of interest}

SLIKA [6] Komplikacije pretilosti i povećanog krvnog tlaka. 


\section{Literatura/References}

[1] Kardiovaskularne bolesti. U: Jakovljević Đ, Grujić V, Martinov-Cvejin M, Legetić B. Socijalna medicina. Novi Sad: Medicinski fakultet; 2003: 144-150.

[2] Ljubas A, Marković M. Zdravstvena njega u kardiologiji jučer, danas, sutra. Medicinski fakultet, Sveučilište u Zagrebu, 2007.

[3] WHO. Cardiovascular disease. Prevention and control. CVD strategy 2001-2002. [cited 2015 Jun 10 1 ]. Available at: http://www.who.int. $\mathrm{ncd} / \mathrm{cvd}$

[4] Strategija za prevenciju i kontrolu hroničnih nezaraznih bolesti Republike Srbije. [cited 2015 Jun 15th]. Available at: http://www.zdravlje.gov.rs/downloads/Zakoni/Strategije/Strategija\%20Za\%20Prevenciju\%20l\%20Kontrolu\%20Hronicnih\%20Nezaraznih\%20Bolesti.pdf. Accessed March 30 th 2017

[5] Kralj V. Kardiovaskularne bolesti. Hrvatski časopis za javno zdravlje 2011; 7(28). [cited 2015 Jul 10]. Available at: http://www.izlog.info/ tmp/hcjz/clanak.php?id=14547

[6] Jakovljević Đ, Planojević M. Dvadeset godina MONICA projekta u Novom Sadu. Institut za kardiovaskularne bolesti Sremska Kamenica i Dom zdravlja Novi Sad 2005: 34-157.

[7] Nešković A, Vlahović A, Otašević P. Ishemijska bolest srca. U: Kardiologija ur. Bojić M, Mirić M. Univerzitet u Beogradu, Beograd 2000.

[8] De Backer G, Ambrosini E, Borch-Johnsen K et al. European guidelines on cardiovascular disease prevention in clinical practice. Third Joint Task Force of European and other Societies on cardiovascular disease prevention in clinical practice. Eur Heart J 2003; 24:1601-1610.

[9] National Health and Medical Research Council. Preventive interventions in primary health care - cardiovascular disease and cancer. Report of the Assessment of Preventive Activities in the Health Care System Initiative. Canberra: AGPS, 1996.
[10] Ministarstvo zdravlja Republike Srbije. Nacrt strategije za prevenciju i kontrolu hroničnih nezaraznih bolesti Republike Srbije, Beograd 2007.

[11] Srdić B, Stokić E. Faktori rizika razvoja kardiovaskularnih bolesti u populaciji Novog Sada. Novi Sad, Antropološko društvo Srbije. 2008, (43):398-408.

[12] Daničić L, Tomić S, Milutinović D. Faktori rizika u nastanku koronarne bolesti- mesto i uloga organizatora zdravstvene nege. Medicina danas 2009; 8(10-12):381-85. [cited 2015 Jun 15]. Available at: http://www.medicinadanas.info/images/clanci/medicina_danas_2009/10-12/381-385_nega_2.pdf. Accessed March 30 th 2017

[13] Practice Guidelines For Primary Care Physicians: 2003 ESH/ESC Hypertension Guidelines. Journal of Hypertension 2003; 21(10):17791786.

[14] Manson JE, Tosteson H, Ridker PM et al. The primary prevention of myocardial infarction. N Engl J Med 1992;326:1406-16.

[15] Grundy SM, Benjamin IJ, Burke GL, Chait A, Eckel RH, Howard BV et al. Diabetes and cardiovascular disease: a statement for healthcare professionals from the American Heart Association. Circulation 1999; 100:1134-46.

[16] Grujić V, Martinov-Cvejin M, Ač-Nikolić E, Nićiforović-Šurković O. Epidemiologija gojaznosti odraslog stanovništva Vojvodine. Med Pregl 2005; 63(5-6):292-95.

[17] Nacionalni program prevencije, lečenja i kontrole kardiovaskularnih bolesti u Republici Srbiji do 2020. godine. Službeni glasnik Republike Srbije, Beograd, 2010. 